\title{
A páros megküzdés összefüggései a jóllét mutatóival kisgyermekes anyák körében
}

\section{Connections of dyadic coping with the indicators of well-being within mothers of children under two}

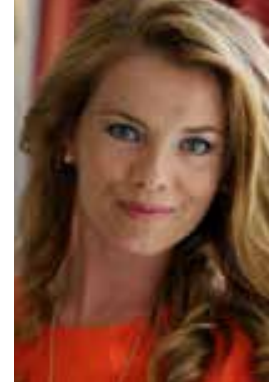

Szerző:

Keresztúri-Nagy Klára

egyetemi hallgató

Munkahelye: SZTE BTK Pszichológia MA.I. évf.

E-mail:k.nklary@gmail.com

Tudományos tevékenysége:

Főbb kutatási területei: kisgyermekes anyák páros megküzdése

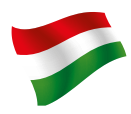

Összefoglalás: A párkapcsolatot érő stresszt többféleképpen, különböző megküzdési stratégiákkal tud megoldani a pár. Az egyik legstresszesebb normatív krízis időszak egy pár életében az első gyermek születése. Az ezzel való megküzdést vizsgáltam az anya szempontjából, vagyis hogy az ő megítélése szerint hogyan kezeli ő saját maga a stresszt, valamint partnere részéről milyen megküzdést érzékel. Az így kapott értékek a jóllét különböző mutatóival is összefüggnek, úgy mint az élettel, párkapcsolattal és otthonnal való elégedettséggel. Kutatásom 2 évnél fiatalabb gyermeket nevelő anyák közül került ki. A speciális minta kevésbé hozzáférhető volta miatt a mintaszám 82 fö, akik főleg a 25-35 éves korosztályt képviselik. A kutatási kérdőívek alskáláinak eredményeit korrelációs vizsgálattal és lineáris regresszióval vizsgáltam. Főbb eredmények között található a partnerrel való elégedettség, mely együttjár a partner részéről érzékelt Támogató páros megküzdéssel, a Közös páros megküzdéssel, az otthonnal és az élettel való elégedettséggel, ugyanakkor negativ összefüggést mutat a partner részéről érzékelt Negativ páros megküzdéssel.

Kulcsszavak: szülővé válás, páros megküzdés, élettel való elégedettség, párkapcsolati elégedettség, otthonnal való elégedettség.

Abstract: Stress in a relationship can be solved by the couple in many ways, with different kinds of coping strategies. One of the most stressful normative crisis periods in a couple's life is the birth of the first child. examined the coping with this event from the mother's aspect, namely in her opinion, how she handles the stress situation, and what kind of coping strategy she detects his pair uses. The received results are related to the indicators of well-being, and the Satisfaction with Life, Relationship, and Home as well. My research examined mothers raising children under the age of two. Since it is a hardly available special sample, the number of the sample is 82 , mainly at the age of 25-35. The outputs of subscales were analyzed with correlation and linear regression. The main result revealed that Satisfaction with Partner correlates with the Supportive Dyadic Coping observed from the partner, also with the Common Dyadic Coping, Satisfaction with Home and Life, whereas showed inverse correlation with the observed Negative dyadic coping.

Keywords: becoming a parent, dyadic coping, Satisfaction with Life, Satisfaction with Relationship, Satisfaction with Home.

A z egyént érő stresszkutatások után egyre nagyobb figyelmet kapott a párkapcsolatot érő stressz, és az a megküzdés, melyIyel a pár kezeli, megoldja a párkapcsolatukat érő problémákat és feladatokat. Az egyik legstresszesebb és legkritikusabb időszak egy pár életében az első gyermek születése, mivel az új családtag érkezése az addig jól megszokott duál múködést felborítja, az új stratégiák pedig még nincsenek kialakulva, amit a trió megkövetel- ne (Hajduska, 2015). Ebben a szenzitív időszakban a stresszkezelés szempontjából nagyon fontos a kapcsolat későbbi alakulása, hogy hogyan kommunikálják a megoldást a pár tagjai külön-külön, együtt, valamint mit érzékelnek a másik felől. Mindezen megküzdési stratégiák eredménye pedig befolyásolják azt, hogy mennyire elégedettek a pár tagjai az életükkel, párkapcsolatukkal és otthonukkal. Kutatásomban arra voltam kíváncsi, hogy azok az anyák, akik még a gyermekük születése utáni normatív krízisüket élik, hogyan kommunikálják saját stresszüket, milyennek érzékelik párjuk stresszkommunikációját, és hogyan értékelik közös erőfeszítéseiket a stressz leküzdése terén - mindez alatt értve azt a stresszt, amely a gyermekkel kapcsolatosan jelenik meg a párkapcsolatban. Végül pedig az így kapott értékek összefüggéseit vetettem össze a jóllét mutatóival.

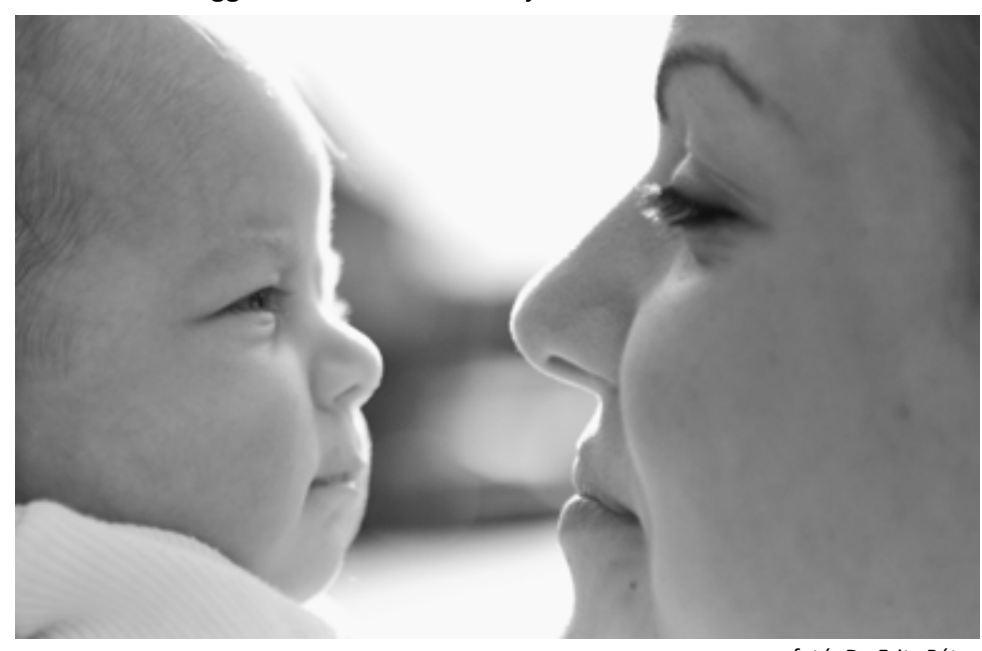

Módszerek:

fotó: Dr. Fritz Péter

Stressz, megküzdés, páros megküzdés. A stressz nem más, mint a szervezet nem specifikus válasza bármilyen igénybevételre (Selye, 1973). A stressz olyan eseményekre utal, melyek által jóllétünk veszélyeztetett. Ezek az események a stresszorok, a rájuk való reakcióink pedig a stresszválaszok (Atkinson-Hilgard, 2005).

A stresszorokat olyan életeseményekkel vizsgálhatjuk és mérhetjük le, melyek kellemetlenül érintik a személyt (Kopp, 2003). Egy ilyen életesemény-skála a Holmes-Rahe nevú életesemény-skála, mely szerint a legsúlyosabb életesemény a házastárs elvesztése, de stresszorként funkcionál a skála szerint az új családtag érkezése vagy a házasságkötés is (Holmes-Rahe, 1967). Holmes és Rahe szerint minden olyan életesemény, amely jelentősebb mértékben kíván alkalmazkodást az egyéntől, stresszesnek tekinthető. Az ilyen élethelyzetekből adódó kellemetlen érzelmek és fiziológiai izgalmak arra ösztönöznek, hogy csökkentsük a stresszt. Ezt a folyamatot nevezzük megküzdésnek (Atkinson-Hilgard, 2005).

Az egyént érő stressz, annak hatásai és a stresszel való megküzdés a tudományágak sokat kutatott szegmense. Az utóbbi években viszont egyre nagyobb hangsúlyt kap az egyéni stressz és a párkapcsolat kölcsönhatásai, és az a folyamat, ahogyan a pár kezeli és megküzd az őt ért megpróbáltatásokkal. A párkapcsolatban megjelenő stressz a pár mindkét tagját érinti, melynek kezelésére a pár egy megküzdési módot alakít ki. Ez a közösen múködtetett folyamat a páros megküzdés, más néven diádikus megküzdés (Randall-Bodenmann, 2009).

Bodenmann és munkatársai több kutatást is végeztek, melyekben a párkapcsolatokban jelen lévő stresszt és a stresszel való 
megküzdés mértékének összefüggéseit vizsgálták a párkapcsolati elégedettség szintjével. Az egyik ilyen kutatásban Bodenmann és munkatársai azt találták, hogy a párkapcsolatban fennálló stressz alacsonyabb kapcsolati elégedettséggel, szexuális elégedettséggel és szexuális aktivitással, ellenben több szexuális diszfunkcióval jár (Bodenmann et al. 2007). A páros megküzdés mérésére alkotta meg Bodenmann a Páros Megküzdés Kérdőívet (Dyadic Coping Inventory, DCl), mely a stresszel való megküzdés módjaira világít rá, mely a stresszt átélő személy kommunikációjából, a probléma partner általi észleléséből, majd a stresszhelyzetre adott közös válaszreakciókból áll.

A kérdőiv a párkapcsolati megküzdéseket vizsgálja: a Pozitiv támogató megküzdést: ebben az esetben a segítő partner nem veszi át a feladatot partnerétől, de támogatja a partner megküzdését, pl. empatikus megértés vagy a probléma elemzésében nyújtott segítség által. Az Átvállalt páros megküzdést: ebben az esetben a segítő partner átveszi a feladat/tevékenység egy részét vagy egészét. És a $\mathrm{Ne}$ gativ páros megküzdést: a partner a problémához és párjához való hozzáállása ellenséges vagy ambivalens, pl.: támogat is, de kritizál is. Végül a Közös páros megküzdést: ebben a megküzdési módban a partnerek mindketten kiveszik részüket, mely lehet problémaközpontú és érzelemközpontú megoldás is (Bodenmann, 2007).

A páros megküzdés által megoldott stresszes élethelyzetek együtt járnak egy magasabb szintű kapcsolati minőséggel és párkapcsolati egészséggel (Bodenmann, 2000). Ebben a közös megküzdésben sikeres párokra jellemzőbb a hosszú távú kapcsolat, a sikeresebb kommunikáció a kapcsolaton belül. A megküzdés mértéke pozitívan korrelál az általános jólléttel, vagyis élettel való elégedettséggel és negatívan a pszichológiai problémákkal. Ezen kutatás arra is rávilágít, hogy a páros megküzdés fontosabbnak bizonyul, mint az egyéni megküzdés, valamint a szociális támogatás, vagyis a környezet támogató attitúdje, mivel a partner és a problémákon való közös felülemelkedés a kapcsolat fontos erőforrása. A párkapcsolatot érő streszszel való közös megküzdés hiánya egyik fő előrejelzője egy későbbi különélésnek és válásnak.

Összességében, a meglévő kutatások azt mutatják, hogy sikeresebb páros megküzdés esetén a párok egy jobb minőségú kapcsolatot tudhatnak magukénak, a kapcsolat kedvezőbb fejlődéssel jár, és alacsonyabb a válás kockázata (Bodenmann et al. 2006).

\section{Élettel való elégedettség}

Diener és munkatársai (1985) szerint az élettel való elégedettség nem más, mint az egyén általános életminőségének kognitiv értékelése a személy szubjektív megítélése alapján. A jóllét és a pozitív életminőség egyik leggyakrabban kutatott ága az élettel való elégedettség, melynek mérésére hozták létre az Élettel való Elégedettség Skálát (Satisfaction with Life Scale, SWLS). Goldstein és munkatársai (1996) szerint a családdá válás folyamatában a jóllétre már a terhesség alatt hatással van a megfelelő támogatási formák elérhetősége, melyeknek hiánya posztnatális depresszióhoz vagy inszenzitív szülői viselkedéshez vezethet. A támogatások forrása az anyai beszámolók alapján a szülést követően a partner és a szülő nő édesanyja, de a jóllét szempontjából a társtól kapott támogatás a jelentősebb hatású az anya jólléte és anyasághoz való alkalmazkodásának szempontjából (Levitt et al. 1986; Cox et al. 1989).

\section{Párkapcsolati elégedettség}

Az emberi kapcsolatok egyik legtöbbet kutatott fogalma a pár, illetve a házastársi kapcsolattal való elégedettség, ami nem más, mint a partnerek szubjektív megítélése saját kapcsolatuk egészéről vagy annak valamely aspektusáról. A párkapcsolati elégedettségnek hatása van a párkapcsolat későbbi alakulására is, valamint ez az egyik bejósló tényezője a kapcsolat stabilitásának, illetve felbomlásának.

A párkapcsolati elégedettség mértéke meghatározhatja az egyén általános jóllétét és lelki egészségét is, de ez a kapcsolat nem feltétlenül egyirányú, hisz az is előfordulhat, hogy akik magasabb mértékú általános jóllétet tudhatnak magukénak, azok általában a párkapcsolataikkal is elégedettebbek (Martos et al. 2014). A párkapcsolati elégedettség mérésére a RAS skálát alkalmaztam (Hendrick, 1988), melyet magyar mintán Martos-Sallay (2014) mutatott be.

\section{Otthonnal való elégedettség}

A szubjektív jóllét és élettel való elégedettség szempontjából vizsgált fontosabb területek a munka, házasság, egészség, anyagi körülmények, lakókörnyezet, barátok stb. (Hagerty et al., 2001), és a vizsgálatok azt mutatják, hogy az egyes részterületekkel kapcsolatos elégedettség erősen korrelál a teljes élettel való elégedettség mértékével, vagyis hogy a területspecifikus elégedettség és az általános elégedettség kölcsönösen jó előrejelzői egymásnak (Heller et al., 2004). Sallay és Martos (2014) azt találták, hogy a szubjektív anyagi helyzet jó bejóslója az otthonnal való elégedettségnek, de korrelációt mutat még az élettel való elégedettség és a párkapcsolattal való elégedettséggel összevetve is.

Az otthon az emberek számára egy fontos helyszín és életterület, mely a fizikai és érzelmi biztonságot tartalmazza, valamint a személyes kontroll és helyidentitás tapasztalatait (Dúll, 1995). Otthonunk ugyanakkor társas és fizikai környezet is egyben, melyek egymással oda-vissza hatva, tranzakcióban jelenítik meg az otthon tapasztalatát (Dúll, 2006).

$\mathrm{Az}$ otthon jelentése általában véve is mást jelent férfinak és nőnek, különösen igaz ez az első gyermek megszületése után. A gyermek születése utáni átmeneti időszakban a nők számára a nemi szerepek tradicionálisabbakká válnak, így nagyobb fokú felelősséget éreznek az otthon rendben tartása és a gyereknevelést illetően (Cowan-Cowan, 1995).

Kaliczki és munkatársai (1998) kimutatták, hogy a gyermek születését követő másfél évben a nők munkája a háztartásban egyre nő, a férfiaké pedig egyre csökken, ami viszont köszönhető többek között az európai átlagot is magasan meghaladó magyar tradicionális szerep szemléletnek, mely szerint a nők dolga az otthon megteremtése és gyermekek gondozása, míg a férfiaké a családfenntartás (Pongrácz, 2005). A párkapcsolati kérdőív analógiájára létrehozott otthonnal való elégedettség skálát Sallay és Martos (2014) hozta létre, és mutatta be magyar mintán, melyet kutatásomban alkalmaztam.

\section{Eredményel}

A kutatás 82 édesanya közremúködésével jött lére, akik 2 évesnél fiatalabb gyermeket nevelnek. a Partnerrel való elégedettség skálával mért adatokban azt találtam, hogy a partnerrel való elégedettséget negatívan jósolja be a gyermek kora, vagyis minél idősebb a gyermek (jelen esetben 0-tól 2 éves korig terjedő skálán), annál elégedetlenebb a partnerével az édesanya. Ennek egyik oka lehet a gyermekkel járó egyre felelősségteljesebb és szélesebb körű feladatrepertoár teljesítése, mely emeli a szülők stressz-szintjét a szülőség terén (Perren et al. 2005), az új szerepek és készségek meg nem szilárdítása és a megszokott rend felbomlása (Cowan et al. 1991), valamint a házasfelek időhiánya, melyet egymással és/vagy egymásra fordíthatnának (Belsky-Rovine, 1990).

Azon eredmények is megmutatkoztak, mely szerint azok az anyák, akik azt érzékelik párjuk felől, hogy empatikus megértéssel fordulnak feléjük, támogatást nyújtanak a problémaelemzésben, és át is vesznek feladatokat az anyától, azok elégedettebbek a párkapcsolatukkal. Ugyanakkor az élettel való elégedettségre pozitívan hat a minél kisebb mértékű észlelt negatív páros megküzdés a partner részéről, ami azt jelenti, hogy minél kevésbé észlel az anya a gyermekük körüli stresszel kapcsolatban kritikus és ambivalens attitúdöt párja felől, annál elégedettebb az életével. Az otthonnal való elégedettség az anyák körében közepesen erős pozitív kapcsolatot mutat a szubjektív anyagi helyzettel. Valószínúleg ez a kapcsolat azért létezik, mert azok, akik anyagi helyzetüket magasabb szintre becsülik, azok otthonukban több elképzelést tudnak megvalósítani ahhoz, hogy elégedettebbek legyenek az otthonuk nyújtotta adottságokkal.

\section{Követleztetésel:}

A szakirodalmi és kutatási előzmények alapján, ha a kisgyermekes anyák párkapcsolatának, élettel és otthonnal való elégedettsége szintjének pozitív befolyásolására keressük a megoldást, nem egyértelmű a válasz. Több kutatás alátámasztja, hogy a partnerrel való kapcsolat minősége miként befolyásolja a párkapcsolat egészét, a stresszel való megküzdést és az általános jóllét érzését a nők/anyák 
körében, ugyanakkor maga a gyermekszületést követő családdá alakulás szakasza egy normatív krízis, ami valószínúleg mindenképp megterheli a család tagjait.

A párok életében bekövetkező stresszes életeseményekkel való megküzdéshez a partnerek egy közös páros megküzdési stratégiát alakítanak ki, mely tartalmazza a saját, a partner és a közös páros megküzdést is. Mindhárom megküzdési stratégia mértéke összefüggésben van egymással és a jóllét mutatóival egyaránt. A párok egyik legkritikusabb életeseménye a gyermek-, főleg az első gyermek születése. Ez a kapcsolatot alapjaiban megrengető életesemény olyan stresszforrás a szülők számára, amellyel a megküzdési stratégiákat a pár mindkét tagjának új alapokra kell építeni, és amely megküzdés

\section{Felhasznált irodalom:}

Atkinson-Hilgard, (2005). Pszichológia. Budapest, Osiris Kiadó

Belsky, J.-Rovine, M. (1990). Patterns of marital change across transition to parenthood: Three eras of research social support across the transition to motherhood: associations with maternal behavior Journal of Family Psychology, 10, 60-71.

Bodenmann, G. (2000). Stress and coping in couples. Göttingen: Hogrefe. Bodenmann, G. (2007). Dyadisches Coping Inventar. Test Manual (Dyadic Coping Inventory. Test Manual). Bern, Switzerland: Huber.

Bodenmann , G-Ledermann

T.-Bradbury, T. N. (2007). Stress, sex and satisfaction in marriage. Personal Relationships, 14, 551-569. DOI: 10.1111/j.1475-6811.2007.00171.x

Bodenmann, G.-Pihet, S.-Kayser, K. (2006). The Relationship between Dyadic Coping, Marital Quality and Wellbeing: A Two Year Longitudinal Study. Journal of Family Psychology, 20, 485-493. DOI: 10.1037/0893-3200.20.3.485

Cowan, C. P.-Cowan, P. A. (1995) Interventions to ease the transition to parenthood: why they are needed and what they can do. Family Relations, 44, 412-423.
Cowan, C. P.-Cowan, P. A.-Heming, G.-Miller, N. B. (1991). Becoming a family: Marriage, parenting and child development. In: Cowan, P. A., Hetherington, M. (Eds.) Family transitions. Lawrence Erlbaum Associates.

Cox, M. J.-Owen, M., Lewis, J.Henderson, V. K. (1989). Marriage, adult adjustment, and early parenting. Child Development, 60, 1015-1024.

Diener, E.-Emmons, E.R-Larsen, R.JGriffin, S. (1985). The Satisfaction With Life

Scale. Journal of Personality Assessment, 49(1), 71-75. http://dx.doi.org/10.1207/ s15327752jpa4901 13

Dúll, A. (1995). Az otthon

környezetpszichológiai aspektusai. Magyar Pszichológiai Szemle, 35, 345-377. o.

Dúll, A. (2006). Környezetpszichológia: szemlélet, elmélet és alkalmazás. In

Bagdy, E., \& Klein, S., (szerk.), Alkalmazott pszichológia, 160-187. o. Budapest: Edge 2000 Kiadó

Goldstein, L. H.-Diener, M. L-

Mangelsdorf, S. C. (1996). Maternal

characteristics and Pregnancy to three years

postpartum. Journal of Marriage and the

Family, 52, 5-19.

Hagerty, M. R.-Cummins, R. A.-Ferriss, A. L.-Land, K.-Michalos, A. C.-Peterson, M., et

eredményeim szerint kevésbé müködik sikeresen a gyermek idősebb korában, ami kutatásomban a 0-2 éves korig terjedő skálán értendő, mint a korai hónapokban.

Ugyanakkor a páros megküzdés alskálái együttjárnak a jóllét mutatóival, úgymint az élettel, párkapcsolattal és otthonnal való megelégedettséggel. Kutatásomban többnyire a pozitív páros megküzdés alskáláin mért értékek pozitívan korrelálnak a jóllét mutatóival, míg a negatív páros megküzdések közül az anya saját negatív páros megküzdése pozitív együttjárást mutat a párkapcsolati elégedettséggel, míg a partnere felől érzékelt negatív páros megküzdés negatívan befolyásolja az élettel, párkapcsolattal és otthonnal való elégedettséget.

al. (2001). Quality of life indexes for national policy: Review and agenda for research. Social Indicators Research, 55, 1-96.

Hajduska, M. (2015). Krízislélektan.

Budapest: ELTE Eötvös Kiadó

Hendrick, S. S. (1988). A generic measure

of relationship satisfaction. Journal of

Marriage and the Family, 50, 93-98.

Heller, D.-Watson, D.-Ilies, R. (2004).

The role of person versus situation in

life satisfaction: A critical examination.

Psychological Bulletin, 130, 574-600. DOI:

10.1037/0033-2909.130.4.574

Holmes, T.,H.-Rahe, R., H. (1967).

Holmes-Rahe life changes scale. Journal of

Psychosomatic Research, 11, 213-218.

Kaliczki, B.-Fthenakis, W. E.-Peitz,

G.-Engfer, A. (1998). Gender-roles at the

transition to parenthood. Poster presented

at the XVth Biennal ISSBD Meeting, Berne.

Kopp, M. (2003). A stressz szerepe az

egészségromlásban. Mikor káros a stressz?

Hippocrates, 5.1.44-49. 0.

Levitt, M. J-Weber, R. A.-Clark, M.

C. (1986). Social network relationships as

sources of maternal support and well-being.

Developmental Psychology, 22, 310-316.

Martos, T.-Sallay, V.-Szabó, T.-Lakatos,

CS.-Tóth, V., R. (2014). A Kapcsolati

Elégedettség Skála magyar változatának
(RAS-H) pszichometriai jellemzői. Mentálhigiéné és Pszichoszomatika 15(3), 245-258. o. DOI: 10.1556/ Mental.15.2014.3.6

Perren, S., von Wyl, A.-Bürgin, D.Simoni, H.-von Klitzing, K. (2005). Depressive symptoms and psychosocial stress across the transition to parenthood: Associations with parental psychopathology and child difficulty. Journal of Psychosomatic Obstetrics and Gynecology, 26, 173-183. DOI: $10.1080 / 01674820400028407$.

Pongrácz, T. (2005). Nemi szerepek társadalmi megítélése. In: Nagy, l., Pongrácz, T., Tóth, I.,Gy. (Eds.). Szerepváltozások Jelentés a nők és a férfiak helyzetéről 2005. TÁRKI - Ifjúsági, Családügyi, Szociális és Esélyegyenlőségi Minisztérium, Budapest. 73-86. 0.

Randall, A., K.-Bodenmann, G. (2009). The role of stress on close relationship and marital satisfaction. Clinical Psychology Review, 29(2), 105-115. doi: 10.1016/j. cpr.2008.10.004.

Sallay, V.-Martos, T. (2014). Az Otthonnal való Elégedettség Skála kidolgozása és pszichometriai jellemzői. Mentálhigiéné és Pszichoszomatika, 15(3), 277-288. o. DOI: 10.1556/ Mental.15.2014.3.8

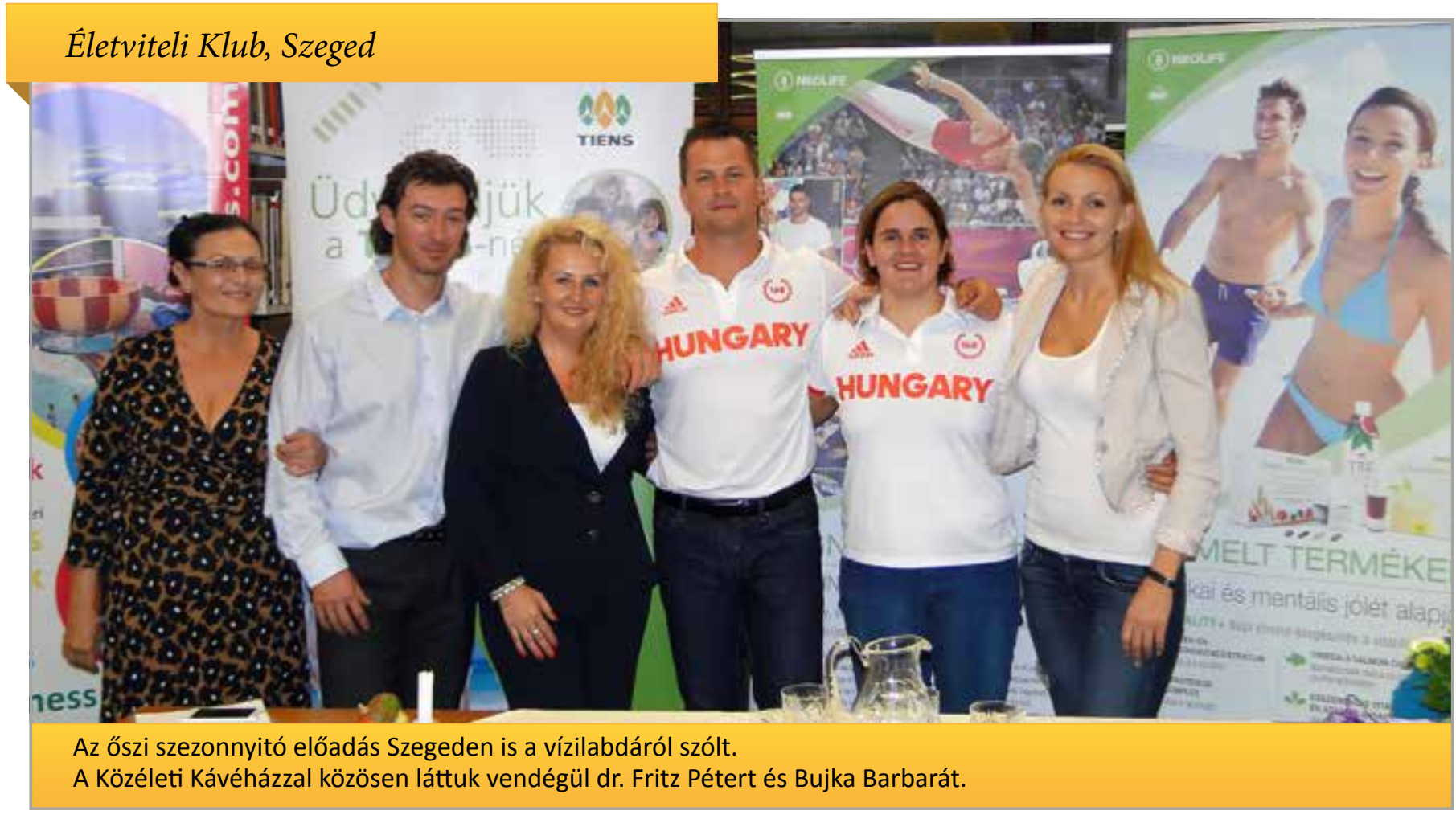

